\title{
砂混じり礫河床上の交互砂州における 流砂動態に関する実験的研究 EXPERIMENTAL STUDY ON SEDIMENT BEHAVIOR ON ALTERNATE GRAVEL-BARS
}

\author{
溝口 敦子 \\ Atsuko MIZOGUCHI \\ 正会員 博(工) 名城大学准教授 理工学部建設システム工学科 \\ （干468-8502 名古屋市天白区塩釜口1-501）
}

\begin{abstract}
These days, more information about the physical surface condition of riverbeds is needed for good river management to be able to take the habitat of river organisms into account. However, it is difficult to examine either sediment conditions at the surface or the substrate structure in detail because of problems in predicting sediment behavior in a real river. Furthermore, the attributes of mixed sediment transport vary depending on physical conditions, making it difficult to describe using numerical simulations. Therefore, a series of flume experiments were conducted in order to examine sediment behavior through alternate bars composed of sand and gravel. These experiments demonstrated the characteristics of fine and coarse sediment movement and indicated the plane distribution of sediment transport on the bars. Additionally, results indicated the impact of fine sediment supply on bed degradation, as well as on bar-morphology.
\end{abstract}

Key Words : Alternate bars, sediment transport, sediment mixture, sediment supply

\section{1. はじめに}

近年，治水だけでなく環境を視野にいれた河川整備の ために必要性が増したことに加え, 数值解析・計測等の 技術・研究も進展したことから，より細かな移動床現象 の解明が行われつつある，例えば，砂州に関する研究に ついて, これまで, 治水上問題となる河道の洗掘深の予 測に必要な波高の予測が活発に行われてきた ${ }^{1)}$. しかし， 数十年のうちに，生物に利用される場など砂州の環境的

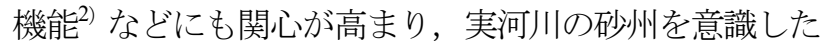
砂州上の粒度分布 ${ }^{3)}$ や砂州の形状とそれを基盤に形成さ れる低水路特性の議論4)，5）も詳細に行われるようにな り，新たな展開を見せている．また，これまでの様々な 移動床現象の知見の集積もあり，理想的な直線河道の議 論だけでなく, 数值解析を用いて実際の河川で起こって いる現象を説明しようとする研究が増えてきている.

このように詳細現象，実河川での現象解明が進む中， 一様粒径でなく混合粒径で構成された河床を対象とした 様々なアプローチも行われつつある.

混合粒径で構成された河床を対象として，河床変動を 数值的に解くためには, 粒径別の流砂量の算定が必要と
なる、これまでには，Egiazarroff式を芦田・道上が修正 した粒径別限界掃流力 ${ }^{6}$ と芦田・道上の粒径別平衡流砂 量式 ${ }^{7)}$ から流砂量を算定し，さらに平野の交換層の理論 8) を用いて河床変動解析を行い, 現象を論じる研究がい くつかおこなわれてきた ${ }^{5)}$ ，9．ただし，この方法は交 換層厚の決定方法などの課題を残していることも指摘さ れており，実際にどこまで適用できるのかについて，明 確にされていない. 一方，特定した現象を追及するため に，一部の河床材料が動かない河床（例えば巨砶と砂が 混在している河床) での掃流砂，浮遊砂量の取り扱いに 関する研究10) 13) など別のアプローチからの研究もおこ なわれてきた. 最近では，さらにそれらを進展させる研 究や，平衡流砂量式を用いず非平衡流砂量の考え方を用 いた解析的アプローチなど多様な研究が活発に行われて いる。例えば，福島ら ${ }^{14)}$ ，関根ら ${ }^{15)}$ ，藤田ら ${ }^{16)}$, Gramsら ${ }^{17)}$ は, 動かない碟で構成された河床からの砂の 抜け出し・充填現象を取り扱った検討を行っており，ま た，溝口 ${ }^{18)}$ は，山地における硯間を流れる砂の掃流砂 量算定方法について実験的検討を行っている. さらに, 長田ら ${ }^{19)}$ は，石碟河川の河床変動をとらえるための数 值解析手法を提案している. 
上記のように，混合粒径で構成された河床の河床変動 や流砂量の予測は，多岐にわたるアプローチがとられて いる．このことからわかるように，混合粒径で構成され た河床は，粒度分布の設定など様々な条件が考えられ， それにより流送形態も異なるなど特有なケースが存在す る. そのために, 平衡流砂量について一意的に予測式を 決めるのは難しいと言える.つまり, 混合粒径について は，ある程度条件を想定した検討をする必要があり，か つ，すべての条件に適応する予測式が確立されていない ために，現状では，実験などを用いて実現象を検討する ことが重要となる.

そこで, 本研究では, 混合粒径で構成された河床の中 でも特に碩河道を想定した基礎現象を調べるため砂混じ り碩で構成された河床を用いた実験を行い, 砂州形成時 の堆積構造や流砂量特性について調べる。これまでの混 合粒径河床上の砂州の特徵を調べた研究は，様々な状況 下で表層の粒度構成や波高に着目し，議論をしているも のがほとんどである ${ }^{20)}$ 。また，土砂供給の粒度分布等 に着目した研究は行われておらず，河床下の状態や砂の 流下速度について検討した例はない，本研究ではそれら に着目し，まず実験を用いて，おこりうる現象を調べた。

ここで, 本研究に関連のある砂混じり磁河床の流砂動 態として, 既往の研究の一部を示す. 鈴木・加藤 ${ }^{21)}$ は, Parkerが指摘した動的粗粒化に伴う鉛直分級に着目し， 実験を用いて調べ，元河床から流水経験後の表層粒度分 布を予測する式の検討を行っている．また，池田・伊勢 屋22)，23) は，砂の流れの上に碩が滑るように流れる現象 が存在することを指摘し，鈴木ら ${ }^{24)}$ は，砂碩混合河床 における礫集合部の形成を論じるのにあたり，池田らが 示した鉛直分級が卓越する条件が存在することを指摘し ている. また, 池田・伊勢屋は, 砂混じり碩河床の特徽 を論じるにあたり，同じ条件でも砂のみの河床より碩が ある程度混じっていた方がより流砂量を増加させるケー スが存在することを指摘している.これについて鈴木ら 25) は実験的に検討し, 㗂の突出効果や遮蔽効果, 細砂 による減摩効果, 粗砂による連行効果について検討を 行っている.一方, 海外では, Wilcockら $\left.{ }^{26)}, 27\right)$ が, そ れらに関わる現象に着目し，砂河川を対象として現象を 論じるには，礫間に存在する砂が㗂の流れに及ぼす影響 が重要と考え，それらを考慮し粒径別限界掃流力に相当 するreference shear stressを検討し，二粒径および複数混 合粒径に対応した独自の流砂量式を提案している.

こうした成果を受け，ここでは，上述した砂混じり砶 河床特有の流砂現象による砂州の粒度分布構造の特徵に ついて調べる. また，䃇床に大きな影響を与えうる砂と 礫の供給比に着目し，表層粒度等について検討を行った。

なお，実河川における砂州は非定常流量下で形成され ており，一定流量で形成された砂州の特徴とは異なる可 能性も否めない. しかし, 砂州形成時に起こる現象やそ の特徵を知ることは基礎的知見を得るために重要であり,
かつ，簡便性からも一定流量で実験を行うこととした．

\section{2. 平衡状態における砂州上での土砂の流れおよ び堆積層の粒度分布の特徵}

\section{（1）砂州形成実験概要}

実験は，砂混じり碩で構成された砂州の動態を調べる ため，ステンレス壁を有する幅 $30 \mathrm{~cm}$ ，長さ $16 \mathrm{~m}$ 水路を 用いて，表-1の条件で実験を行った。

水路の概要を図-1に示寸．水路には，前述のように碩 床河川の河床条件を意識し, 主材料として三河珪砂 3 号

(平均粒径 $2.2 \mathrm{~mm}$ 程度), 副材料として5 号（平均粒径 $0.55 \mathrm{~mm}$ 程度) を $8: 2$ で混ぜ合わせ，流下方向に約 $12.5 \mathrm{~m}$ の区間を厚さ $7.5 \mathrm{~cm}$ で敷き均した。下流では横断方向の 偏りがわかるように，5分割した採砂箱を置き，流出土 砂を採取した．上流では，土砂供給装置を用いて，予備 実験での計測值を参考に決めた混合割合および量の土砂 を定常的に投入した，なお，予備実験では，土砂供給を 行わず上流からの河床低下が伝播しない短時間で実施し, 河床高, 下流端からの土砂流出量, その粒度を計測した。

実験開始直後に，ポイントゲージを用いて水深を計測 し，実験中には，流下方向 $60 \mathrm{~cm}$ おきに計測断面を設定 し，レーザー変位計を用いて各横断面の河床高を計測し た．あわせて，下流端での土砂の採取，砂州の動きを把 握するために前縁線位置のスケッチ, 砂の流れを把握す るためにビデオ撮影などを行った.

\section{（2）砂州の形成状況概要}

実験では，各ケースともに，通水開始10分後には交互 砂州が現れ，発達し，流下していくのが見られた．参考 に，図-2に，計測区間における横断河床高低差の最大值 と定義した砂州波高の時間変化を示寸。この図から，ほ ぼ安定した砂州が形成されているのがわかる.

表-1：実験条件

\begin{tabular}{|c|c|c|c|c|c|c|}
\hline Case & 流量 $\left(\mathrm{m}^{3} / \mathrm{s}\right)$ & 勾配 & $\begin{array}{c}\text { 水路幅 } \\
(\mathrm{m})\end{array}$ & $\begin{array}{c}\text { 初期平均水深 } \\
(\mathrm{cm})\end{array}$ & $\begin{array}{l}\text { 供給土砂量 } \\
(\mathrm{g} / \mathrm{min} / 0.3 \mathrm{~m})\end{array}$ & $\begin{array}{l}\text { 土砂供給割合 } \\
\text { 粗砂: 細砂 }\end{array}$ \\
\hline $\mathrm{A}$ & 0.003 & $1 / 82$ & 0.3 & 2.1 & 540 & $10: 1$ \\
\hline B & 0.0018 & $1 / 50$ & 0.3 & 1.8 & 700 & $47: 3$ \\
\hline
\end{tabular}

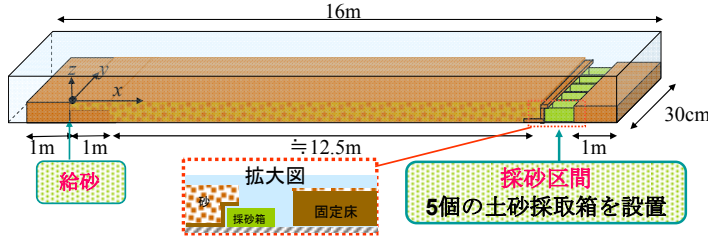

図-1 実験水路概要

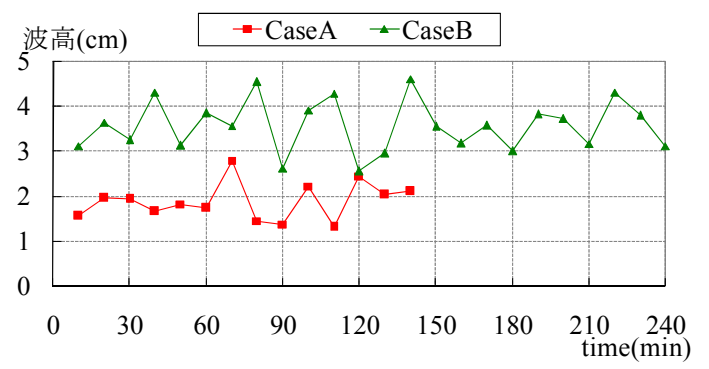

図-2＼cjkstart各実験における波高の時間変化 


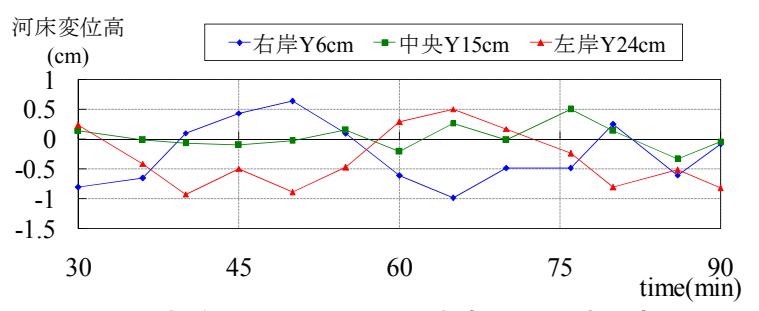

図-3＼cjkstart実験CaseAにたける河床変位量の時間変化

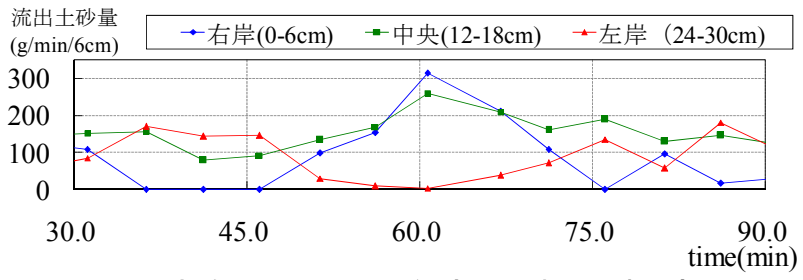

図-4＼cjkstart実験CaseAlにおける総流出土砂量の時間変化

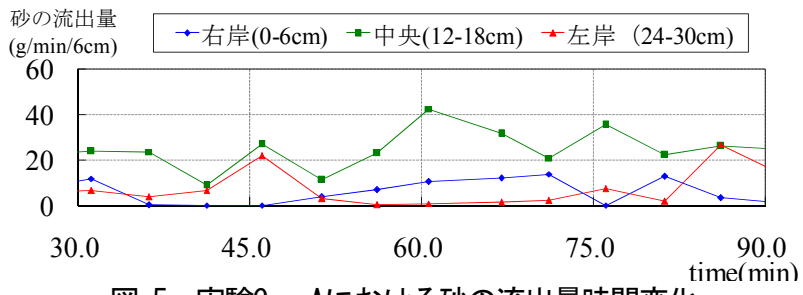

図-5 実験CaseAににおける砂の流出量時間変化

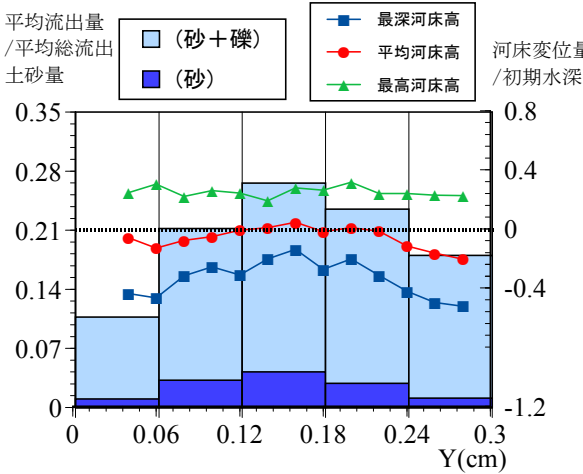

図-6 実験CaseAlにおける縦断方向平均 ・ 最高 · 最深河床高横 断形状と横断方向への流出土砂の偏り

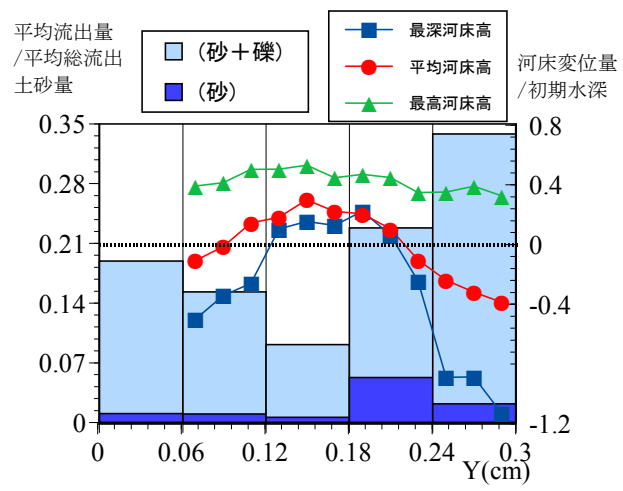

図-7 実験CaseBIにおける縱断方向平均 - 最高 - 最深河床高横 断形状と横断方向への流出土砂の偏り

\section{（3）流出流砂量から見る砂州上の流下土砂量の特徵}

下流からの流出土砂量を調べたところ，砂州の形成に 伴い，流出土砂量は，横断方向に偏りを見せた．図-3〜 5に，下流端での河床高，砂と碟を合わせた総流出土砂 量，砂のみの流出土砂量の時間変化について，一波長分 の砂州が流下した時間帯を抽出し，左右岸および水路中
央の值で示寸これれよると，河床高，総流出土砂量は 左右岸付近で大きく変動しているが，砂については，常 に中央で多く流出していることがわかる．また，左右岸 の河床高のピークと総流出土砂量のピークはずれており, 左右岸それぞれ，高い值を示した後に総流出土砂量が増 加していることが分かる. 砂州の形成に伴う総流出土砂 量の変動は，著者が以前に示した一様粒径の砂州形成時 28) と同様であるが，砂の流出状況が異なっている．ほ ぼ平衡状態となった砂州河床からの土砂流出状態につい て横断面での特徵を調べると, 縱断方向に平均した河床 高の横断形状が，藤田らに指摘された横断方向への土砂 の動きによって形成されるかまぼこ型形状を強く有して いるCaseBとそうでないCaseAでは, 総流出土砂量の横 断的偏りの傾向が異なり, 特にメイン材料の砂の流出が 壁面または水路中央部で多くなっている（図-6，7）. ただし，細粒分の砂については，どちらもピークが壁面 付近でなく, 特にCaseAでは明確に水路中央付近で多く 流出していることがわかる，これは，交互砂州の形成過 程に砂と礫が水路中央に運ばれる過程で，砂が砂州堆積 域に捕捉されるために壁面付近でなく水路中央よりでの 流出が多くなると考えられる. なお，実験は再現性の確 保のため2回以上行い，同様な結果を確認している。 ま た，堆積域一の砂の捕捉については，後述する.

\section{(4) 着色土砂の投入による砂州形成時の表層および堆積 層の状態に関する検討}

砂州形成後，供給土砂を青と赤に着色した砂碩に切り 替え2時間程度通水し, 通水停止後に断面を切り出し写 真撮影により，堆積層の様子をうかがった。

その結果を図-8, 9に示寸. 砂州流下時の土砂の入れ 替わりは, 着色土砂で示される層で起こっていることが 予測される. CaseBでは着色土砂と無着色士砂の境目の 形状がどの断面でも同じ形でみられる，写真から位置を 読夕取ったところ, 図一7に示した縦断方向最深河床高と おおよそ同じ位置を示しており, 縦断方向最深河床以上 の領域で土砂の入れ替わりが起こっていると言える.ま た, 着色士砂の下層で青色の砂が水路中央にまとまって 存在しており堆積部に捕捉されていることがわかる.こ れについては, CaseAでも, 同様の傾向が見られた.

着色土砂の縦断方向の分布について調べると，両ケー スともに赤色に着色した碩は下流部まで確認されるが， 青色の砂は比較的上流部にのみ存在しており, 本実験条 件では，砂と砂の流下速度が格段に異なることがわかる. これらは，すべて砂混じり碩河床の特徴が深く関係して いる. 第一章に既往の研究成果で示したように, 砂の存 在割合が小さい場合，移動床表層は粗粒化し砂は碩に隠 れた状態で少ない量流下寸る傾向にあり, 表層は元河床 よりも粗粒化する. この特徵と砂州の形成時の砂砅の流 れにより, 水路中央部に運ばれた礫と砂のうち, 砂は中 央部の下層に比較的多く捕捉されながら運ばれ, 碩は, 速く流下していくと言える. 
なお，混合粒径で構成された河床を対象に行われた既 往の研究と同様に，本実験でも，砂州前縁付近に細粒分 が多く見られた（図-9）。これは，砂州の堆積域つまり 前縁線の上流部まで砂の下に隠れた状態で碩とともに流 送されていた細粒分が，砶とともに前縁付近に堆積する のに対し, 深掘れ部では掃流力が強く動的粗粒化を起こ し，かつ，細粒分がとどまれないことにより起こってい ると考えられる.こうした砂州特有の流れのメカニズム により，砂州の形成とともに細粒分は水路中央部分に多 く運ばれ堆積層に補足され, 結果として下流からの流出 も中央部でのみ多く確認されると言える. なお，通水後， 表層を薄くはぎ，碩の存在割合をCaseAで測定したとこ ろ，図-10に示すように，左右岸の深掘れ部で高く，中 央部で元河床程度となっていた．このことからも，左右 岸は粗粒化していることがわかり，水路中央部に砂が多 く存在していることが確認される.

\section{3. 土砂供給条件による砂州地形の変化と流砂量, 表層粒度の変化}

\section{(1) 検討内容}

混合粒径河床は，上流からの土砂供給条件により， 様々な影響を受ける可能性がある，特に，表層の粗粒化 が起きる本設定条件では，碩と砂の供給比により表層粒 度が変化し，河床の状況も変化する可能性がある．供給 土砂の質の重要性に着目し，前節のCaseA，Bを基本 ケースとし，砂州形成後供給条件を表のように変化させ る実験を行った.

\section{表-2 切り替え後の土砂供給条件}

\begin{tabular}{|c|c|c|c|c|c|}
\hline Case & $\begin{array}{c}\text { 供給土砂量 } \\
(\mathrm{g} / \mathrm{min} / 0.3 \mathrm{~m})\end{array}$ & 礫: 砂 & Case & $\begin{array}{c}\text { 供給土砂量 } \\
(\mathrm{g} / \mathrm{min} / 0.3 \mathrm{~m})\end{array}$ & 礫:砂 \\
\hline $\mathrm{A} 0$ & 0 & - & $\mathrm{B} 0$ & 0 & - \\
\hline $\mathrm{A} 1$ & 540 & $2: 1$ & $\mathrm{~B} 1$ & 700 & $0: 1$ \\
\hline $\mathrm{A} 2$ & 540 & $1: 2$ & & & \\
\hline $\mathrm{A} 3$ & 540 & $0: 1$ & & & \\
\cline { 1 - 2 } & & & &
\end{tabular}

\section{（2）土砂供給の質が及ぼす影響}

上流から供給される土砂の細粒化は，まず，表層粒度 を変化させ，水理条件を変化させるために，河床形態を も変化させる可能性が高い，本実験で，CaseA2，A3の ように砂の供給割合を増加させると，砂は基本ケースよ り速く, 砂州の表面を覆うように流下していった（図11）. CaseA2，A3においては，この変化とともに，初 期に形成されていた砂州は徐々に波高を低くした（図一 12）。また，砂の供給により，河床材料が活発に動き出 し，図-13に示すように，流出土砂量はいっきに増加す る. 砂の割合を多く供給すればするほど，供給を変化さ せた時から下流からの流出土砂量が増加するまでに要す る時間が，短いことが確認された。 同時に砂の流下速度 も増加しており, 例えば, 着色士砂の供給に切り替えて から下流端で着色砂が流出するまでに要する時間は，基 本ケースとなるCaseAでは, 比較的速い砂粒で40分程度
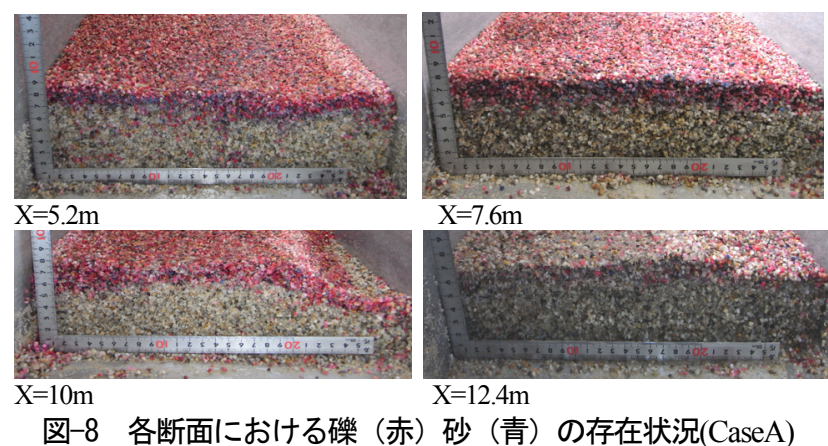

$\mathrm{X}=12.4 \mathrm{~m}$

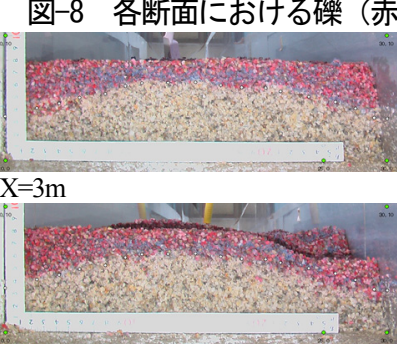

\section{$\mathrm{X}=4.5 \mathrm{~m}$}

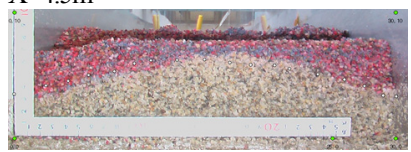

$\mathrm{X}=6 \mathrm{~m}$

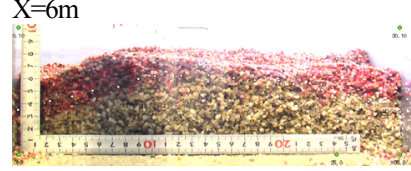

$\mathrm{X}=11 \mathrm{~m}$

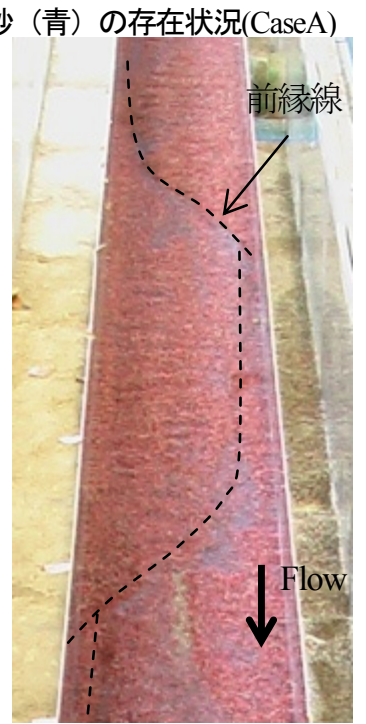

図-9＼cjkstart各断面および表層における

礫（赤）砂（青）の存在状況(CaseB)

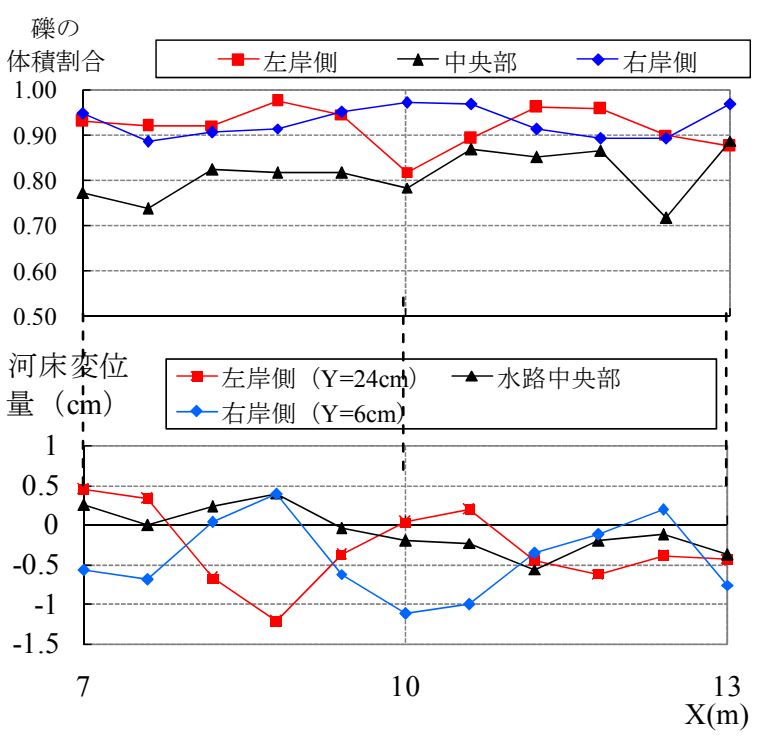

図-10 左右岸・中央における河床高と礫の体積割合（CaseA）

要しているにも関わらず，CaseA2では，わずか10分後 となった．これは，表層の砂の割合が多いと，礫が砂を 覆うように流下してきて砂州にいったん捕捉される過程 が無くなり，より速く流下寸るようになると考えられる。

なお，本実験では，供給する碩と砂の割合を変化させ ただけで，供給する量を一定に保っている．しかし，細 砂の供給は，流出土砂を増加させることから，河床低下 を起こした. 河床低下は，上流から起きていることが， 縦断方向に示した横断方向平均河床高の時間変化を示寸 

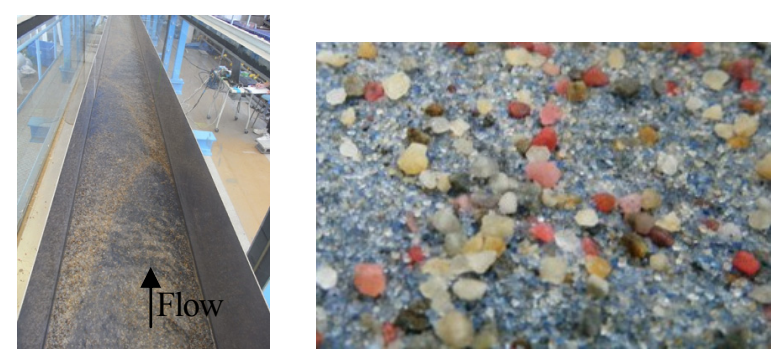

図-11 CaseA3時の砂で覆われていく砂州の様子（左）と CaseA2時の砂上で浮き上がって動いていた礫の痕跡（右）

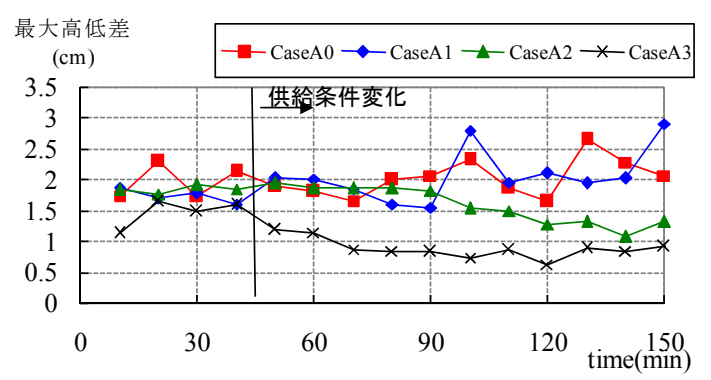

図-12 CaseA0-A3における波高の変化

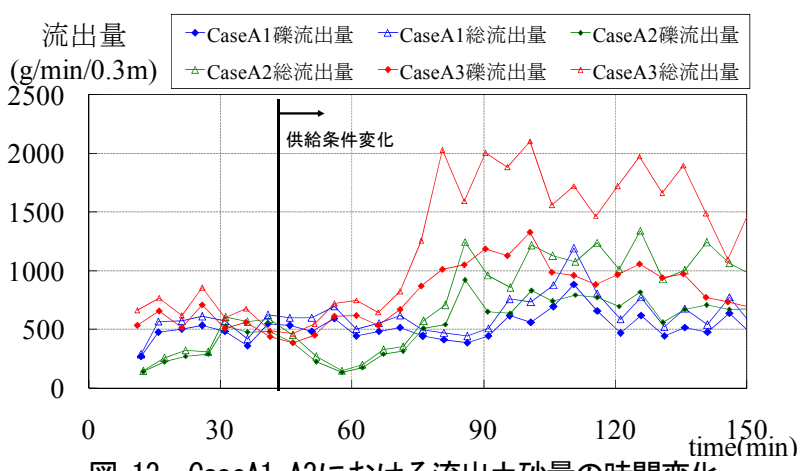

図-13 CaseA1-A3における流出土砂量の時間変化

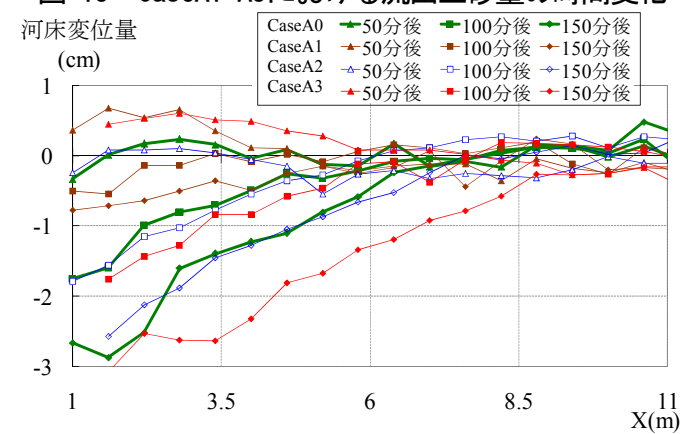

図-14 CaseA0-A3における横断方向平均河床変化量 河床変化量

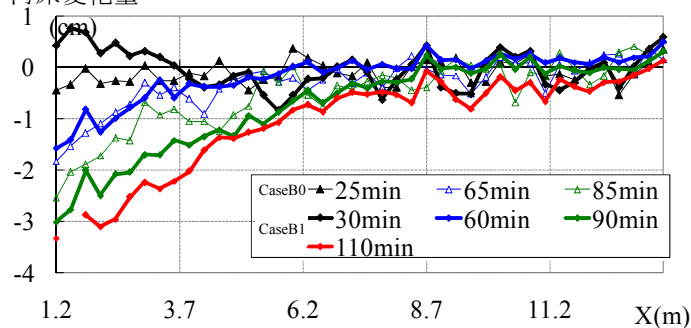

図-15 CaseB0-B11における横断方向平均河床変化量

図-14，15から確認できる．興味深いことに，河床低下 の状況は，砂のみの供給ケース（CaseA3，B1）により， 土砂供給をしないケース（CaseA0，B0）のほうが，低 下の進行速度が遅くなっている。 つまり, 砂の供給は, 㗂を活発に動か寸ため，砂磎ともに供給しないより，河

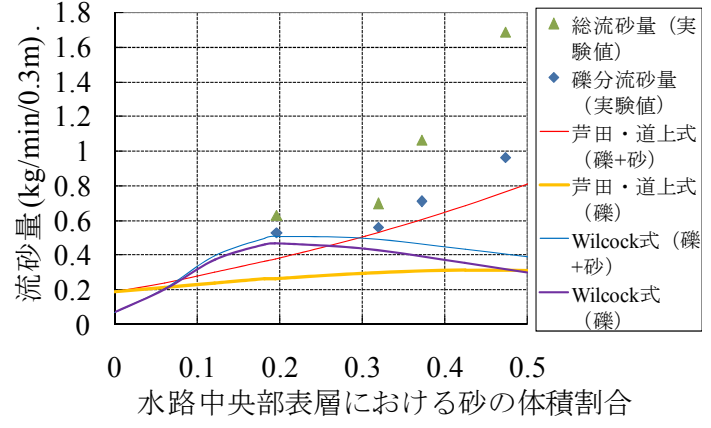

図-16＼cjkstart水路中央表層における砂の体積占有率と流砂量

床を細粒化させながら低下させるといえる，実際に，池 田ら 22) が指摘した砂の流れが砂を浮き上がらせて流下 する現象がCaseA2，A1で見られ（図-11），砂の表層割 合が高いときの特有の現象がみられた.

\section{4. 砂混じり礫河床における課題}

第 $2 ， 3$ 章の検討から，砂混じり碩河床の土砂動態が 砂州形成河道の表層, 下層を含めた粒度環境に非常に重 要な役割を示していることがうかがえる．第 1 章に示し た既往の研究にあるような砂まじり碩河床の流砂挙動, つまり動的粗粒化や鉛直分級が，砂州の形成時に砂州堆 積域に砂を捕捉する．また，砂混じり礫河床の土砂動態 には，土砂供給およびそれで決まる表層粒度の状態が非 常に重要となる，その決まり方は，単純でなく，特に， 砂の供給条件の変化が河道に与える影響は深刻であるた め，この現象を追求する必要がある.

実験から得られた水路中央部表層における砂の体積占 有割合（実験後表層をはぎ取り計測）と流出土砂量の関 係を図-16に示す，なお，それにあわせ，砂混じり碩河 床（砂の割合36\%まで）で検討されたWilcockらの式 ${ }^{26)}$ と芦田・道上の式から算出される粒径別流砂量を参考に 合わせて示寸．また，表層粒度は，左右岸付近で粗く中 央付近で細かいため横断的なばらつきがあるが，細粒分 が多くなるA2，A3ではばらつきが少なくなるため，中 央值で代表させ図を描写している，この図によると，実 験值は，表層の砂の体積割合が 0.3 以上となるところか ら，急激に碩と砂ともに流砂量が増えていることが確認 される．細粒分割合 0.2 の実験值流砂量には，砂州によ る河床の凹凸および流砂量の平面分布の影響が含まれて おり，流砂量式との比較は難しい。しかし，細粒分が多 いケースについては，砂州波高は低く，それほど砂州に よる影響を受けておらず，かつ，流砂量は時間的にほぼ 一定，下流部の平均河床高は縦断的にほぼ一定になって いることから平衡流砂量としてみなせるとすると，細粒 分の増加による碩流砂量の増加は，これまでの平衡流砂 量算定モデルでは表現できていないことが分かる．これ までの流砂量モデルには，例えば，表層でおこる砂の流 れが砂を持ち上げ流送する効果など砂混じり礫河床特有 の現象はとりこまれておらず，著者が以前に検討した数 值解析モデル9 を適用しても，砂州は描写できるが堆積 
層の粒度分布，つまり水路中央部の細粒化の描写はでき なかった. 今後, 砂混じり碩河床特有の現象を意識した うえで，さらなる現象の解明，検討が必要だと考える.

\section{5. 結論}

本研究では, 砂混じり礫河床を対象とし, 砂州の形成 に伴う粒度の変化, 流砂特性の変化およびそれに土砂供 給条件が及ぼす影響を調べる実験を行った．その結果か ら, 以下の現象が現れることを示した.

・砂州形成実験でも，従来から言われているように表層 粗粒化がみられ，この影響を受け，堆積層の粒度分布 が形成された。つまり，砂州形成時には，砂州特有の 砂の流孔と砂と碩の鉛直分級現象によって, 細粒分の 砂は, 水路中央に集まり, 堆積層に多く存在した.

・砂州横断形状（いわゆるかまぼこ型形状）の発達の有 無により流れが変化するため，主材料となる碩の流出 は, 砂州横断形状が発達している場合は壁際で多く, 発達していない場合は水路中央部で多い.

・土砂供給があってもその粒径が河床構成主材料より細 かくなれば，表層粒度をいち早く変化させ，河床を活 発に動かすことで広範囲で河床形状が大きく変化する とともに，その供給量が少なければ上流部から河床低 下が促進される.

既往の研究で指摘されているように，砂を多く含む河床 は砶のみの河床より土砂を活発に動か寸，そのため，砅 床河川に供給される土砂の砂の量と割合は, 砂州河道に 大きな影響を与える可能性があることが本研究により示 された．特に河床の主材料よりも細かいものを多く投入 寸る際には，その量によって河床形態の変化や河床低下 を促進する可能性があり，注意が必要となる，逆にいえ ば，礫床河川において細粒分の供給量が減っているため に，予想以上に砂が動かなくなっている河道がある可能 性もある. 今後, 今回取り扱った現象をつきつめ, 現象 の詳細や解析的な再現を検討寸るとともに，実河川の現 象に照らしあわせ，その重要性を確かめる必要がある.

\section{参考文献}

1) 例えば, 村本嘉雄, 藤田裕一郎 : 中規模河床形態の分類と形 成条件，第22回水理講演会論文集，1978.

2) 例えば, 尾花まき子, 辻本哲郎 : 砂州河川の景観と河川生態 系の構造にもとづく生態的機能評価へのアプローチ, 土木学 会水工学論文集 , Vol.53, pp.1183-1188， 2009.

3) 例えば, 忠津哲也, 下條康之, 内田龍彦, 福岡捷二 : 洪水流 による砂州の移動・変形と砂州粒度構成の変化, 河川技術論 文集，Vol.16，pp.119-124，2010.

4) 例えば，益本孝彦，渡邊康立，佐々木章允 : 洪水減水期にお ける水みち形成に関する実験，河川技術論文集，Vol.16， pp.119-124, 2009.

5) 例えば, 寺本敦子, 辻本哲郎 : 砂州形状の特性と平水時の流 路構造，水工学論文集，第50巻，pp.961-966， 2006.

6) 芦田和男, 道上正規 : 移動床流れの抵抗と掃流砂量に関寸る 基礎的研究，土木学会論文集，第206号，pp.59-69. 1972.

7) 中川博次, 辻本哲郎 : 移動床流れの水理, 技報堂出版, 1986.
8) 平野宗夫 : Armoringを伴う河床変動について, 土木学会論文 集, No.195, pp.55-65, 1971.

9) 例えば, 寺本敦子, 辻本哲郎 : 卓越砂州モード数へ及ぼす河 床の粒度構成の影響, 水工学論文集, 第48巻, 土木学会, pp.1003-1008, 2004.

10) 村本嘉雄, 河田恵昭, 布村明彦 : 砂䃯河川の掃流砂に関す る基礎的研究，京大防災研年報第20号B-2，pp.451-474， 1977.

11) 芦田和男, 藤田正治 : 河床粒子の浮遊機構とそのモデル化, 第375号/II-6, pp.79-88, 1986.

12) 芦田和男, 藤田正治 : 平衡および非平衡浮遊砂量算定の確 率モデル, 土木学会論文集, 第375号/ II -6, pp.107-116, 1986.

13) 道上正規, 藤田正治, 北川豊広, 三村光太郎 : 空隙の大き な河床一の浮遊砂の沈み込み過程と非平衡浮遊砂, 水工学論 文集，第38巻, pp.609-614, 1994.

14) 福島雅紀, 未次忠司, 瀬崎智之 : 透礫層の形成とその充填 機構に関する研究, 水工学論文集, 第50巻, pp.985-990, 2006.

15) 関根正人，林将宏 : 礫・シルト充填河床モデルを用いた碟 河道の準二次元河床変動解析, 水工学論文集, 第51巻, pp.973-978, 2007.

16) 藤田光一, 山原康嗣, 冨田陽子, 伊藤嘉奈子, 小路剛志 : 大碟床表面における砂の堆積状況と浮遊砂量との関係につい ての実験的研究，水工学論文集，第52巻, pp547-552, 2007.

17) P. E. Gram \& P. R. Wilcock: Equilibrium entrainment of fine sediment over a coarse immobile bed, Water Resources Research, Vol. 43, W10420, 2007.

18) 溝口敦子 : 大礫間を流れる砂の流砂量算定に向けた相対水 深が小さい場での粗度抵抗・有効掃流力の評価に関する実験 的検討，応用力学論文集，第13巻，pp. 869-876，2010.

19) 長田健吾, 福岡捷二 : 石礫蛇行河川の二次元河床変動解析 法に関する研究，河川技術論文集，Vol. 15，pp.327-332， 2009.

20) 例えば，三輪浩，大同淳之，片山智仁 : 交互砂州河床の変 動に及ぼす流量・土砂供給条件の影響, 水工学論文集第51巻, pp. 1051-1056, 2007.

21) 鈴木幸一, 加藤幸一 : 動的平衡状態における混合砂碩河床 表層の粗粒化，第33回水理講演会論文集，pp.415-420, 1989.

22) 池田宏, 伊勢屋ふじこ : 粗砂の運ばれやすさに及ぼす細砂 の影響, 筑波大学水理実験センター報告, No.9, pp. 43-47, 1985.

23) H.Ikeda, F. Iseya: Experimental study of heterogeneous sediment transport, Experimental Research Center Papers, University of Tsukuba, 1988.

24) 鈴木幸一, 山本裕規, 藤岡貴之 : 礫集合部の形成と破壊に よる混合砂砶河床の流砂量変動, 水工学論文集, 弟41巻, pp. 801-806, 1997.

25) 鈴木幸一, 栗原崇, 山本裕規 : 二粒径混合砂碑による流砂 量に及ぼす砂碟の混合効果の検討, 水工学論文集, 第38巻, pp. 627-632, 1994.

26) Wilcock, P.R. and S.T. Kenworthy "A two fraction model for the transport of sand/gravel mixtures", Water Resources Research. vol.38. 10, pp. 1194 - 2003, 2002.

27) Wilcock, P.R. and J.C. Crowe "A surface-based transport model for sand and gravel", J. Hydraulic Engineering, vol.129. 2, pp. $120-$ $128,2003$.

28) 溝口敦子, 辻本哲郎 : 砂州形成河床上の流砂量と流砂動態 の検討，水工学論文集，第52巻，pp.589-594， 2008.

29) 藤田裕一郎, 村本嘉雄, 堀池周二 : 交互砂州の発達に過程 に関寸る研究, 京都防災研年報, 第24号B-2, pp.411-431, 1971.

(2010. 9. 30受付) 